Volume 13

Number 4 Vol. 13, No. 4 Climate Change

Article 12 and Global Security

\title{
Environmental Crime in Transnational Context: Global Issues in Green Criminology. By Toine Spapens, Rob White, \& Wim Huisman. New York, N.Y.: Routledge, 2016.
}

William Dittmann, Ph.D.

Angelo State University, william.dittmann@angelo.edu

Follow this and additional works at: https://digitalcommons.usf.edu/jss

pp. 160-163

\section{Recommended Citation}

Dittmann,, William Ph.D.. "Environmental Crime in Transnational Context: Global Issues in Green Criminology. By Toine Spapens, Rob White, \& Wim Huisman. New York, N.Y.: Routledge, 2016.." Journal of Strategic Security 13, no. 4 (2020) : 160-163.

DOI: https://doi.org/10.5038/1944-0472.13.4.1895

Available at: https://digitalcommons.usf.edu/jss/vol13/iss4/12

This Book Review is brought to you for free and open access by the Open Access Journals at Digital Commons @ University of South Florida. It has been accepted for inclusion in Journal of Strategic Security by an authorized editor of Digital Commons @ University of South Florida. For more information, please contact digitalcommons@usf.edu. 
Environmental Crime in Transnational Context: Global Issues in Green Criminology. By Toine Spapens, Rob White, \& Wim Huisman. New York, N.Y.: Routledge, 2016. 


\section{Environmental Crime in Transnational Context: Global Issues in Green Criminology. By Toine Spapens, Rob White, \& Wim Huisman. New York, N.Y.: Routledge, 2016. ISBN 978-1-138-60656-2. Pp. xiv, 309. \$52.95.}

Environmental Crime in Transnational Context: Global Issues in Green Enforcement and Criminology, is a collection of works from various scholars that cover the relatively new concept of green criminology, environmental crimes and harms, and theoretical perspectives that explain how and why these harms occur. From local and regional issues to the impact of worldwide environmental crimes and harms, the authors of this text do an impeccable job describing and examining these atrocities and the effect that they have on our world. Although green criminology is but a 20 year old term, many of the environmental issues noted in this text have impacted regions around the world for ages. This green criminology text will help readers better understand what exactly green criminology is, the wide range of crimes and harms that fit within this concept, the numerous challenges that are faced when attempting to address these crimes and harms, and frameworks for future studies that seek to explore environmental crimes through a green criminology lens.

Regardless of a reader's level of knowledge of environmental crime and green criminology, this text is organized in a way that allows any reader to understand the concepts, perspectives, and impacts that surround these types of crimes and harms. Part one of this book (The Global Context of Environmental Crime and Green Criminology) contains the first four chapters. Chapter one eloquently presents the idea of a global green criminology, and explains how social and economic norms are often used to contest or dispute claims of environmental harms. This chapter also provides explanations for blatant environmental atrocities, mostly centered around profits, denial of harms, and issues with the presence, or lack thereof, laws and enforcement capabilities. Chapter two outlines three important strategies that can be used to address these atrocities including enforcing pre-existing laws, reducing opportunities for perpetrators, and using social pressures and shaming of perpetrators. Chapter three covers the issue of transnational wildlife trafficking by explaining the nexus between wildlife trafficking, the high demand and price for these products, 
and the potential for massive profits paid to individuals in source countries that lack other financial opportunities. Chapter four provides numerous examples of hydrocarbon and resource extraction as elite crimes. The author neatly places green criminology within previous criminological theories, and explains how green criminology can be used as another tool in the criminologist toolbox to address these crimes and harms.

Part two focus on law enforcement responses to transnational environmental crimes. Chapter five uses the example of e-waste, or the disposal of obsolete technology devices, as a form of cross border crime, and provides a detailed account of how the European Union (E.U.) has responded to this type of environmental crime from an intelligence-led policing and intervention effort approach. Chapter six outlines the role of the three core agencies responsible for enforcing laws that are related to transnational environmental crimes: environmental regulatory agencies (ERAs), customs and port authorities (CPAs), and police agencies (PAs). This chapter also covers three responses to these types of crimes (administrative sanctions or responses, civil penalties or remedies, and prosecution in a criminal court), along with their unique challenges. The chapter concludes with a focus on local and transnational networking and the role that information sharing can play in intervention and enforcement. Chapter seven uses an important case study to highlight some of the legal challenges with transnational fishery crimes, notably identifying the victim/s of such crimes under the public trust doctrine, and how compensation is to be distributed among other victims. Chapter eight concludes part two by diving further into legal issues and interpretations related to victimization of environmental crimes and harms, along with four specific problems specialty courts have when hearing these types of cases.

Part three contains four chapters that each highlight alternative methods for combating transnational environmental crime, and do not rely on law enforcement. Chapter nine introduced the notion of New Environmental Governance (NEG) which relies more on cooperation, partnerships, and agreements among public, private, and non-government agencies and individuals, as opposed to the enforcement of regulations. Chapter ten explores the idea of employing a deliberative democracy approach to addressing environmental crime and harm issues. This alternative 
approach would essentially rely on randomly sampled public opinion polls, to explore sentiments about environmental crimes and help inform decision-making by taking into consideration the beliefs and values held by citizens. Chapter eleven explores the deterrent effect that sanctions have on waste industry companies in the Netherlands, with interesting findings that speak to the deterrent power of morally condemning and publicly shaming these companies over other traditional methods of deterrence (p. 204). Chapter twelve describes the EU Emissions Trading system (ETS), its effectiveness, and some of the issues that exist across its member states.

Part Four focuses on studies that have used criminology-based research approaches when examining transnational environmental crime and harms. Chapter thirteen provides a unique methodological framework for examining elicit environmental networks and their actors. I found this chapter to be useful on all fronts. Similar to the way social network analysis (SNA) is used in investigations of traditional organized crime groups, SNA can also be employed for these groups of environmental criminals as the methods suggested may help with intel collection, investigations, law enforcement, the future development of legislation, future research, and by providing the specialty courts with valuable information about illicit network actors and their roles in these types of crimes. One thing that was missing from this chapter was an actual example of the framework in action. Chapter fourteen discusses the use of photo-elicitation interviews in qualitative data collection, and the benefits of this survey approach. Chapters fifteen presents case studies on the relationship between organized crime and illegal waste disposal in Campania, Italy, while chapter sixteen compares the migration of humans and non-humans, and raises questions as to whether or not, and when, humans and a non-human animals are considered native.

In sum, the authors of this text do well at not only explaining the concept of environmental crime and criminology, but also explaining the complexities of enforcing and curbing transnational environmental crimes and harms. The broader message taken from this text is that addressing environmental crimes and harms requires awareness and the will to do so. Although the will may exist in some more developed countries, addressing these types of crimes also requires personnel, legislation, effective specialty courts, and resources. Restructuring concerns over crimes of this 
type and magnitude from the typical "not in my backyard" (NIMBY) approach to a "Not In Anyone's Backyard" or "Not On Planet Earth" (NOPE) approach, collectively reframes these types of crimes as having a global impact and creates a sense of conviction and responsibility to address them (p. 21). Given the uptick in natural disasters in the context of climate change and the massive efforts towards rebuilding after these disasters, one concern is that authorities may not be able to allocate the time and resources necessary to combat environmental crimes. This concern is even greater for underdeveloped countries and marginalized populations. Despite the many challenges noted in this book, I remain hopeful that both this text and this special issue will play a role in raising awareness, explaining the harms of environmental crimes, and creating a sense of collective will in addressing climate security and the impacts of transnational environmental crime through a green criminology research lens.

W. Layne Dittmann, Ph.D., Angelo State University 